\title{
A multi-scale comparison of modeled and observed seasonal methane emissions in northern wetlands
}

\author{
Xiyan Xu ${ }^{1}$, William J. Riley ${ }^{1}$, Charles D. Koven ${ }^{1}$, Dave P. Billesbach ${ }^{2}$, Rachel Y.-W. Chang ${ }^{3,4}$, Róisín Commane ${ }^{3}$, \\ Eugénie S. Euskirchen $^{5}$, Sean Hartery ${ }^{4}$, Yoshinobu Harazono ${ }^{6,7}$, Hiroki Iwata ${ }^{6,8}$, Kyle C. McDonald ${ }^{9,10}$, \\ Charles E. Miller ${ }^{10}$, Walter C. Oechel ${ }^{11,12}$, Benjamin Poulter ${ }^{13}$, Naama Raz-Yaseef ${ }^{1}$, Colm Sweeney ${ }^{14,15}$, \\ Margaret Torn $^{1,16}$, Steven C. Wofsy ${ }^{3}$, Zhen Zhang ${ }^{13,17}$, and Donatella Zona ${ }^{11,18}$ \\ ${ }^{1}$ Earth Sciences Division, Lawrence Berkeley National Laboratory, Berkeley, California, USA \\ ${ }^{2}$ Biological System Engineering Department, University of Nebraska, Lincoln, Nebraska, USA \\ ${ }^{3}$ School of Engineering and Applied Sciences, Harvard University, Cambridge, Massachusetts, USA \\ ${ }^{4}$ Department of Physics and Atmospheric Science, Dalhousie University, Halifax, Nova Scotia, Canada \\ ${ }^{5}$ Institute of Arctic Biology, University of Alaska Fairbanks, Fairbanks, Alaska, USA \\ ${ }^{6}$ International Arctic Research Center, University of Alaska Fairbanks, Fairbanks, Alaska, USA \\ ${ }^{7}$ Graduate School of Life and Environmental Sciences, Osaka Prefecture University, Sakai, Osaka, Japan \\ ${ }^{8}$ Department of Environmental Sciences, Faculty of Science, Shinshu University, Matsumoto, Nagano, Japan \\ ${ }^{9}$ Department of Earth and Atmospheric Sciences, CUNY Environmental Crossroads Initiative and NOAA-CREST Institute, \\ The City College of New York, City University of New York, New York, USA \\ ${ }^{10}$ Jet Propulsion Laboratory, California Institute of Technology, Pasadena, California, USA \\ ${ }^{11}$ Global Change Research Group, Department of Biology, San Diego State University, San Diego, California, USA \\ ${ }^{12}$ Department of Environment, Earth and Ecosystems, The Open University, Milton Keynes, MK7 6AA, UK \\ ${ }^{13}$ Department of Ecology, Montana State University, Bozeman, MT 59717, USA \\ ${ }^{14}$ Cooperative Institute for Research in Environmental Sciences, University of Colorado, Boulder, Colorado 80304, USA \\ ${ }^{15}$ NOAA Earth System Research Laboratory, Global Monitoring Division, Boulder, Colorado, USA \\ ${ }^{16}$ Energy and Resources Group, University of California-Berkeley, Berkeley, California, USA \\ ${ }^{17}$ Swiss Federal Research Institute WSL, Birmensdorf 8059, Switzerland \\ ${ }^{18}$ Department of Animal and Plant Sciences, University of Sheffield, Sheffield, S102TN, UK
}

Correspondence to: Xiyan Xu (xxu@lbl.gov)

Received: 29 April 2016 - Published in Biogeosciences Discuss.: 9 May 2016

Revised: 5 August 2016 - Accepted: 24 August 2016 - Published: 13 September 2016

\begin{abstract}
Wetlands are the largest global natural methane $\left(\mathrm{CH}_{4}\right)$ source, and emissions between 50 and $70^{\circ} \mathrm{N}$ latitude contribute $10-30 \%$ to this source. Predictive capability of land models for northern wetland $\mathrm{CH}_{4}$ emissions is still low due to limited site measurements, strong spatial and temporal variability in emissions, and complex hydrological and biogeochemical dynamics. To explore this issue, we compare wetland $\mathrm{CH}_{4}$ emission predictions from the Community Land Model 4.5 (CLM4.5-BGC) with siteto regional-scale observations. A comparison of the $\mathrm{CH}_{4}$ fluxes with eddy flux data highlighted needed changes to the model's estimate of aerenchyma area, which we imple-
\end{abstract}

mented and tested. The model modification substantially reduced biases in $\mathrm{CH}_{4}$ emissions when compared with CarbonTracker $\mathrm{CH}_{4}$ predictions. CLM4.5 $\mathrm{CH}_{4}$ emission predictions agree well with growing season (May-September) CarbonTracker Alaskan regional-level $\mathrm{CH}_{4}$ predictions and sitelevel observations. However, CLM4.5 underestimated $\mathrm{CH}_{4}$ emissions in the cold season (October-April). The monthly atmospheric $\mathrm{CH}_{4}$ mole fraction enhancements due to wetland emissions are also assessed using the Weather Research and Forecasting-Stochastic Time-Inverted Lagrangian Transport (WRF-STILT) model coupled with daily emissions from CLM4.5 and compared with aircraft $\mathrm{CH}_{4}$ mole fraction mea- 
surements from the Carbon in Arctic Reservoirs Vulnerability Experiment (CARVE) campaign. Both the tower and aircraft analyses confirm the underestimate of cold-season $\mathrm{CH}_{4}$ emissions by CLM4.5. The greatest uncertainties in predicting the seasonal $\mathrm{CH}_{4}$ cycle are from the wetland extent, coldseason $\mathrm{CH}_{4}$ production and $\mathrm{CH}_{4}$ transport processes. We recommend more cold-season experimental studies in highlatitude systems, which could improve the understanding and parameterization of ecosystem structure and function during this period. Predicted $\mathrm{CH}_{4}$ emissions remain uncertain, but we show here that benchmarking against observations across spatial scales can inform model structural and parameter improvements.

\section{Introduction}

Natural wetlands are the largest natural methane $\left(\mathrm{CH}_{4}\right)$ source, contributing up to $34 \%$ of global $\mathrm{CH}_{4}$ emissions (Kirschke et al., 2013). Between 1980 and 2009, estimated global annual $\mathrm{CH}_{4}$ emissions from wetlands varied from 115 to $231 \mathrm{Tg} \mathrm{CH} \mathrm{CH}_{4}$ in top-down atmospheric inversion models and 169 to $284 \mathrm{Tg} \mathrm{CH}_{4}$ in bottom-up process-based land models (Kirschke et al., 2013). Peat-rich bogs and fens lying between 50 and $70^{\circ} \mathrm{N}$ constitute about half of the global wetland area and release 10-30\% of the total wetland $\mathrm{CH}_{4}$ (Wania et al., 2010; Zhuang et al., 2004; Bergamaschi et al., 2009; Riley et al., 2011). Much of the northern wetland area is in the permafrost zone, which stores $1035 \pm 150 \mathrm{Pg}$ soil organic carbon for the $0-3 \mathrm{~m}$ soil depth (Hugelius et al., 2014). When permafrost soils thaw, $\mathrm{CH}_{4}$ is produced under anaerobic conditions by methanogenic archaea. Once $\mathrm{CH}_{4}$ is produced, it can be oxidized by methanotrophic archaea. $\mathrm{CH}_{4}$ surface emissions occur through several transport pathways: aqueous and gaseous diffusion, ebullition, and aerenchyma diffusion and advection. At any point in the soil, the $\mathrm{CH}_{4}$ concentration is governed by the balance between $\mathrm{CH}_{4}$ production in anoxic zones, $\mathrm{CH}_{4}$ consumption in oxic zones, transport, and atmospheric $\mathrm{CH}_{4}$ diffusion at the soil-atmosphere interface.

Many interacting factors (e.g., temperature, thaw depth, soil moisture, depth of the water table, vegetation type) affect $\mathrm{CH}_{4}$ production and emission. $\mathrm{CH}_{4}$ production has a positive response to temperature increase (Van Hulzen et al., 1999; van Winden et al., 2012; Hommeltenberg et al., 2014), and laboratory incubations of soil samples from the active layer show that large variability of $Q_{10}$ values for $\mathrm{CH}_{4}$ production (1.5 to 28 , Segers, 1998) is related to site-specific peatland type and organic matter quality (Lupascu et al., 2012). $\mathrm{CH}_{4}$ emissions also show positive temperature dependence above freezing. The temperature dependence of surface $\mathrm{CH}_{4}$ emission is much stronger than that of respiration and photosynthesis, which indicates increases in both $\mathrm{CH}_{4}$ emissions and the ratio of $\mathrm{CH}_{4}$ to $\mathrm{CO}_{2}$ emissions with seasonal increases in temperature (Yvon-Durocher et al., 2014). The positive temperature dependence of $\mathrm{CH}_{4}$ emissions may only be valid when $\mathrm{CH}_{4}$ oxidation is less sensitive to temperature (van Winden et al., 2012). The $Q_{10}$ value for $\mathrm{CH}_{4}$ oxidation was reported to be 1.4 to 2.1 in northern peat soils (Dunfield et al., 1993). Strong oxidation temperature sensitivity can lead to decreased $\mathrm{CH}_{4}$ surface emissions with rising temperature (Wang et al., 2014). The positive dependence of $\mathrm{CH}_{4}$ emissions on soil temperature can be most significant in areas with sufficient soil moisture or a shallow water table (Roulet et al., 1992; Moosavi et al., 1996; Wickland et al., 1999). The dependency of $\mathrm{CH}_{4}$ emissions on temperature can vanish at a high temperature and low water table (Hommeltenberg et al., 2014). At low water table levels, large $\mathrm{CH}_{4}$ oxidation can mask the $\mathrm{CH}_{4}$ production temperature sensitivity in the net emissions. $\mathrm{CH}_{4}$ production under sub-zero temperatures was reported in incubation experiments (Clein and Schimel, 1995; Brouchkov et al., 2003); however, the mechanisms that regulate $\mathrm{CH}_{4}$ production under cold temperatures have not been clarified.

Soil water content exerts a strong control on $\mathrm{CH}_{4}$ emissions by affecting belowground carbon decomposition and root growth (Iversen et al., 2015). A lowered water table typically reduces $\mathrm{CH}_{4}$ production and emission because of a higher aerobic-to-anaerobic respiration ratio in the soil column and $\mathrm{CH}_{4}$ oxidation during diffusive transport through the oxygen-rich surface layer (Whalen and Reeburgh, 1990). If $\mathrm{CH}_{4}$ produced in anoxic zones (e.g., below the water table) is transported to the atmosphere through aerenchyma, the impact of methanotrophy on net $\mathrm{CH}_{4}$ emissions is diminished (Bartlett et al., 1992; Torn and Chapin, 1993; King et al., 1998; Juutinen et al., 2003; McEwing et al., 2015). The reduced methanotrophic impacts vary with vascular species cover and root density and are more common in tall vegetation because taller plants have more extensive root systems that enable more methanogenesis and pore water $\mathrm{CH}_{4}$ to escape to the atmosphere (van Fischer et al., 2010). The correlation between water table depth and $\mathrm{CH}_{4}$ emission can be very weak if the water table drops in an already oxic surface layer (Sturtevant et al., 2012).

The seasonal cycle of $\mathrm{CH}_{4}$ emissions and their physical controls are strongly controlled by the freeze-thaw cycle in northern wetlands and regulation of wetland extent. The northern wetland area retrieved from the 19 and $37 \mathrm{GHz}$ passive microwave Special Sensor Microwave/Image (SSM/I) brightness temperature database shows that maximum inundation is usually observed during July, August and September in North America $\left(48-68^{\circ} \mathrm{N}\right)$ and between June and September in northern Eurasia (Mialon et al., 2005). The inundation dynamics retrieved from the Special Sensor Microwave Imager (SSM/I) and the International Satellite Cloud Climatology Project (ISCCP) observations, European Remote Sensing (ERS) scatterometer responses, and Advanced Very High Resolution Radiometer (AVHRR) visible and near-infrared reflectance also show that maximum in- 
undation occurs in July and August in northern boreal regions $\left(55-70^{\circ} \mathrm{N}\right.$; Prigent et al., 2007). The inferred wetland extent increases rapidly during the spring thaw period and shrinks again during the fall freeze period, though it is unclear on large scales how much of this seasonal cycle is due to changes in the areal fraction of land in which water ponds at the surface versus changes in the phase of that water. The interannual variability of high-latitude summer wetland extent is very small. Larger interannual variability during the intermediate seasons arises from the large variability of the timing and extent of snowmelt and accumulation (Mialon et al., 2005). For boreal bogs north of $50^{\circ} \mathrm{N}$, the variation in wetland area contributed about $30 \%$ to the annual emissions and can explain the interannual variation in regional $\mathrm{CH}_{4}$ emissions (Ringeval et al., 2010).

Site measurements have shown great variability in seasonal $\mathrm{CH}_{4}$ emissions (Wilson et al., 1989; Mastepanov et al., 2008; 2013; Zona et al., 2016). In the late fall to winter, the surface water or shallow peat zone are frozen, and $\mathrm{CH}_{4}$ produced below the frozen layer can be trapped. Only a small portion of the trapped $\mathrm{CH}_{4}$ is oxidized because of low oxygen concentrations below the frozen layer (Mastepanov et al., 2008). Observed $\mathrm{CH}_{4}$ emissions during spring thaw are highly variable and contribute substantially to total annual emissions. $\mathrm{CH}_{4}$ fluxes during the spring thaw period contributed $11 \%$ to the annual budget over an aapa mire in Finnish Lapland (Hargreaves et al., 2001). The emission amounts can be $24 \%$ of the total annual emissions during the spring period after snowmelt next to an open pool in Caribou Bog, Maine, while the proportion can be as high as $77 \%$ in the adjacent upland area (Comas et al., 2008). In the non-inundated upland tundra, the cold-season (September to May) emissions account for more than $50 \%$ of the annual $\mathrm{CH}_{4}$ emissions (Zona et al., 2016). Although wetlands can contribute a large proportion of annual $\mathrm{CH}_{4}$ emissions during the cold season, the seasonal peak of $\mathrm{CH}_{4}$ emissions is usually observed in the summer (Pickett-Heaps et al., 2011; Zona et al., 2016). A transport model combined with flight measurements showed the peak $\mathrm{CH}_{4}$ emission to be in JulyAugust in the Hudson Bay Lowlands (Pickett-Heaps et al., 2011). Although the recorded emission pulses during spring thaw and late fall (Song et al., 2012; Tokida et al., 2007; Rinne et al., 2007; Mastepanov et al., 2008, 2013) may be more localized and of minor importance to annual emissions (Chang et al., 2014; Rinne et al., 2007), the pulses indicates the complexity and heterogeneity in the seasonal $\mathrm{CH}_{4}$ cycle.

Many modeling studies have shown that there is large uncertainty in predictions of spatial patterns of $\mathrm{CH}_{4}$ emissions from natural wetlands on the regional and global scales (Melton et al., 2013; Bohn et al., 2015). This uncertainty can be roughly split into poor knowledge of water table and soil moisture dynamics versus poor knowledge of $\mathrm{CH}_{4}$ fluxes per unit area of land with a given water table depth or soil moisture state; both contribute substantially to the overall uncertainty. One approach to reducing this overall uncertainty is to focus on the seasonal cycles of $\mathrm{CH}_{4}$ emissions on the site scale (where inundation dynamics can be more easily constrained) versus on larger scales to ask whether model predictions and errors are consistent across these scales. The temporal dynamics of $\mathrm{CH}_{4}$ emissions over the season cannot be ignored when calculating long-term $\mathrm{CH}_{4}$ budgets (Morin et al., 2014). To investigate the seasonal cycle of $\mathrm{CH}_{4}$ emissions in northern wetlands and the underlying processes in a climate model context, we evaluated and modified the $\mathrm{CH}_{4}$ biogeochemistry module in the Community Land Model (CLM 4.5). Seasonal cycles of $\mathrm{CH}_{4}$ emissions in Alaskan wetlands are analyzed based on the modified model predictions, $\mathrm{CH}_{4}$ emission measurements at high-latitude sites, CarbonTracker $\mathrm{CH}_{4}$ emission estimates and atmospheric inversion estimates of surface $\mathrm{CH}_{4}$ emissions from data collected in the Carbon in Arctic Reservoirs Vulnerability Experiment (CARVE). The models and data are described in Sect. 2. Multi-scale comparison results and discussions are given in Sect. 3 and concluding remarks in Sect. 4.

\section{Data and methods}

\subsection{Model descriptions}

\subsection{1 $\mathrm{CH}_{4}$ model in CLM4.5-BGC}

The $\mathrm{CH}_{4}$ biogeochemistry model used here (CLM4Me; Riley et al., 2011) has been coupled to the revised land model CLM4.5, which includes numerous changes to vegetation, soil biogeochemistry and hydrology from the CLM4.0 in which CLM4Me was originally developed. CLM4Me includes the representation of $\mathrm{CH}_{4}$ production, oxidation and transport through the soil column. Transport includes multiple pathways: aerenchyma transport, ebullition, and aqueous and gaseous diffusion. Aerenchyma is the most efficient pathway for gas exchange between the soil and atmosphere in wetlands or aquatic environments, through which atmosphere $\mathrm{O}_{2}$ is supplied to roots and the rhizosphere while $\mathrm{CH}_{4}$ is removed from the soil to shoots and the atmosphere. In CLM4Me, aerenchyma transport $(A)$ is parameterized as gaseous diffusion in response to a concentration gradient between the soil layer $(z)$ and the atmosphere $(a)$ as

$A=\frac{C(z)-C_{\mathrm{a}}}{\frac{r_{\mathrm{L}} z}{D p T \rho_{r}}+r_{\mathrm{a}}}$,

where $D\left(\mathrm{~m}^{2} \mathrm{~s}^{-1}\right)$ is the free-air gas diffusion coefficient, $C$ $\left(z ; \mathrm{mol} \mathrm{m}^{-3}\right)$ is the gaseous concentration at depth $z$, dimensionless $r_{\mathrm{L}}$ is the ratio of total root length to root depth, $p(-)$ is tiller porosity, $T\left(\mathrm{~m}^{2} \mathrm{~m}^{-2}\right)$ is specific aerenchyma area, $r_{\mathrm{a}}$ $\left(\mathrm{s} \mathrm{m}^{-1}\right)$ is the aerodynamic resistance between the surface and the atmospheric reference height and $r_{\mathrm{L}}(-)$ is the root mass fraction in the soil layer. The aerenchyma area $T$ is sea- 
sonally varying with phenology $S$ (described below):

$T=\frac{f_{\mathrm{N}} N_{\mathrm{a}} S}{0.22} \pi R^{2}$,

where $N_{\mathrm{a}}\left(\mathrm{g} \mathrm{C} \mathrm{m}^{-2}\right)$ is annual net primary production (NPP), $R\left(2.9 \times 10^{-3} \mathrm{~m}\right)$ is the aerenchyma radius, $f_{\mathrm{N}}$ is the belowground fraction of current NPP, and the factor $0.22(\mathrm{~g} \mathrm{C})$ is the mass of C per tiller. The dimensionless term $S$ is included in CLM4Me to capture seasonal cycles of aerenchymous tissues. In the absence of data on phenology of aerenchyma, $S$ was originally taken as the leaf area index (LAI).

The default method for calculating inundation fraction $\left(F_{\text {def }}\right)$ remains the same as described in Riley et al. (2011), which applied a simple inversion model to represent the spatial inundation:

$F_{\text {def }}=p_{1} e^{-z_{\mathrm{w}} / p_{2}}+p_{3} Q_{\mathrm{r}}$.

The three parameters $\left(p_{1}, p_{2}, p_{3}\right)$ are optimized with the inundation map by Prigent et al. (2007). $z_{\mathrm{w}}$ is simulated water table depth (m) and $Q_{\mathrm{r}}$ is surface runoff $\left(\mathrm{mm} \mathrm{s}^{-1}\right)$. We also applied an estimate of inundation fraction $F_{S+G}$ derived from seasonal cycle of inundation fraction from the Surface WAter Microwave Product Series Version 2.0 (SWAMPS; Schroeder et al., 2015) developed at the NASA Jet Propulsion Laboratory with the Global Lakes and Wetlands Dataset (GLWD; Lehner and Doll, 2004) to discuss the potential uncertainties in $\mathrm{CH}_{4}$ emissions caused by wetland area.

Our model is driven by half-degree CRUNCEP V5 6-Hourly Atmospheric Forcing dataset (1901-2013; http://esgf.extra.cea.fr/thredds/fileServer/store/p529viov/ cruncep/readme.htm). Monthly wetland $\mathrm{CH}_{4}$ emissions are simulated between the year 2000 and 2012 during which $F_{S+G}$ is available. The monthly $\mathrm{CH}_{4}$ emissions in half-degree resolution are regridded to $1^{\circ} \times 1^{\circ}$ and averaged longitudinally to compare with CarbonTracker-predicted $\mathrm{CH}_{4}$ fluxes. Daily wetland $\mathrm{CH}_{4}$ emissions are simulated for the years 2012 and 2013 to calculate the atmospheric enhancements of $\mathrm{CH}_{4}$ due to modeled surface emissions.

\subsubsection{WRF-STILT modeling of $\mathrm{CH}_{4}$ transport}

We simulate the atmospheric $\mathrm{CH}_{4}$ mole fraction enhancements due to wetland emissions by combining the CLM4.5predicted daily surface emissions with the land surface influences ("footprint") calculated by the Weather Research and Forecasting-Stochastic Time-Inverted Lagrangian Transport (WRF-STILT) model (Henderson et al., 2015). WRF-STILT estimates the upwind surface influence along the flight track of the CARVE aircraft by releasing 500 particles at the point of flight measurement and allowing them to stochastically disperse in reverse time over 10 days (Henderson et al., 2015). The resolution of the resulting footprint sensitivity used in this study is $0.5^{\circ} \times 0.5^{\circ}$, covering $30-90^{\circ} \mathrm{N}$, circumpolar. However, we assume that $\mathrm{CH}_{4}$ transported from areas outside of Alaska are most likely mixed thoroughly in the atmosphere before they reach Alaska and therefore only contribute to the background abundance of $\mathrm{CH}_{4}$.

\subsection{Measurements of $\mathrm{CH}_{4}$}

\subsubsection{Site-scale observations}

We compare CLM4.5 $\mathrm{CH}_{4}$ emission predictions with data obtained from published studies and recent measurements of Northern Hemisphere static-chamber (SC) measurements at 10 sites and eddy covariance (EC) measurements at 10 sites, of which 8 are in Alaska (Supplement Table S1). The eddy covariance measurements in Alaska (Fig. S2) are obtained at the Barrow Environmental Observatory (BEO1) tower operated by the Next Generation Ecosystem Experiment (NGEE)-Arctic group; the Barrow Environmental Observatory tower (BEO2), the Biocomplexity Experiment South (BES) tower, the Climate Monitoring and Diagnostics Laboratory (CMDL) tower, the Atqasuk (ATQ) tower and the Ivotuk (IVO) tower operated by Global Change Research Group at San Diego State University (Zona et al., 2016); the tower in Fairbanks (FAI; Iwata et al., 2015) operated by the International Arctic Research Center, the University of Alaska Fairbanks; and the tower at the Imnavait Creek watershed (IMN; Euskirchen et al., 2012). Monthly means are calculated across each observational record to compare to the predicted mean seasonal $\mathrm{CH}_{4}$ cycle. We discarded the monthly mean if the number of valid measurement days is less than half a month.

\subsubsection{Comparisons to airborne measurements}

The regionally integrated $\mathrm{CH}_{4}$ mole fraction enhancements over Alaska were calculated from the $\mathrm{CH}_{4}$ mole fractions measured by NOAA and Harvard Picarro spectrometers aboard a NASA C-23B aircraft (N430NA) during CARVE aircraft flights (Chang et al., 2014). The Harvard $\mathrm{CH}_{4}$ measurements were gap filled with the NOAA $\mathrm{CH}_{4}$ measurements to create a continuous $5 \mathrm{~s}$ time series. The flight measurements were conducted on selected days from May to September in 2012 and April to October in 2013 during the Carbon in Arctic Reservoirs Vulnerability Experiment (CARVE) campaign for a total of 31 flight days in 2012 and 43 flight days in 2013 (Supplement Fig. S1 and Table S2). The measurements of $\mathrm{CH}_{4}$ with concurrent $\mathrm{CO}$ mole fractions above $150 \mathrm{ppb}$ are excluded to remove possible $\mathrm{CH}_{4}$ production from biomass burning. In Alaska, atmospheric boundary layer depth is in the range of $1100-1600 \mathrm{~m}$ above ground level (a.g.l.) during April and October according to COSMIC satellite and Radiosonde data (Chan and Wood, 2013). We assume that the observed concentration fluctuations below $500 \mathrm{~m}$ a.g.l. can be used to infer the variation of surface $\mathrm{CH}_{4}$ fluxes; the measurements above $1600 \mathrm{~m}$ a.g.l. are used to infer the background mole fraction of $\mathrm{CH}_{4}$. 
The monthly mean enhancements in observed atmospheric $\mathrm{CH}_{4}$ mole fraction are compared to that estimated from the CLM4.5 $\mathrm{CH}_{4}$ enhancements.

\subsubsection{Comparisons to global-scale inversions}

To compare our methane emissions with global- and regional-scale inversions, we use monthly regional $\mathrm{CH}_{4}$ emissions predicted by CarbonTracker (Peters et al., 2007; Bruhwiler et al., 2014) at $1^{\circ} \times 1^{\circ}$ resolution. In CarbonTracker estimates, the natural $\mathrm{CH}_{4}$ emissions correspond to wetlands, soils, oceans, insects and wild animals. To examine the land $\mathrm{CH}_{4}$ emissions only, we apply the CLM land mask to exclude the inferred CarbonTracker $\mathrm{CH}_{4}$ emission from the ocean surface. CarbonTracker $\mathrm{CH}_{4}$ estimates are available from January 2000 through December 2010; we therefore limit comparisons against the CLM4.5 predictions to this period.

\section{Results and discussion}

\subsection{Model constraints and comparison with observations}

We performed sensitivity analyses of all the parameters affecting seasonal $\mathrm{CH}_{4}$ production, oxidation and emission pathways and found that the parameterization of aerenchyma transport has the greatest impact on the seasonal $\mathrm{CH}_{4}$ emissions in saturated areas. The $\mathrm{CH}_{4}$ surface flux sensitivity to aerenchyma is most sensitive to aerenchyma area in saturated conditions and decreases with increasing aerenchyma area because increased $\mathrm{O}_{2}$ fluxes through aerenchyma cause more $\mathrm{CH}_{4}$ oxidation in the rhizosphere (Riley et al., 2011). Meng et al. (2012) tested plant-functional-type (pft)-specific fine-root carbon $\left(\mathrm{C}_{\mathrm{FR}}\right)$ as a proxy of aerenchyma area and found that aerenchyma area dependence on $\mathrm{C}_{\mathrm{FR}}$ leads to about $39 \%$ increases in global annual $\mathrm{CH}_{4}$ emissions. In that study, an early spring spike in $\mathrm{CH}_{4}$ emission through aerenchyma transport was shown at a Michigan site in both LAI and $\mathrm{C}_{\mathrm{FR}}$-based aerenchyma area. Our analysis shows that the simulated $\mathrm{CH}_{4}$ burst through aerenchyma transport during spring thaw is very common in areas experiencing winter dormancy. In CLM4.5, $\mathrm{CH}_{4}$ production in a given volume of soil is proportional to heterotrophic respiration (HR) in that soil volume, adjusted by soil temperature, $\mathrm{pH}$, redox potential and variation of seasonal inundation fraction. In the model, $\mathrm{CH}_{4}$ production starts when the soil temperature is above the freezing point. However, CLM4.5 LAI lags behind the primary thaw day, which, because the original representation of aerenchyma in CLM4.5 is tied directly to LAI, results in a very low aerenchyma area and thus low aerenchyma transport of $\mathrm{O}_{2}$ into the soil during the spring thaw period. Only a very small portion of the $\mathrm{CH}_{4}$ produced in the soil column is oxidized, allowing a large fraction of $\mathrm{CH}_{4}$ to be transported to the surface by aerenchyma. The low oxida-

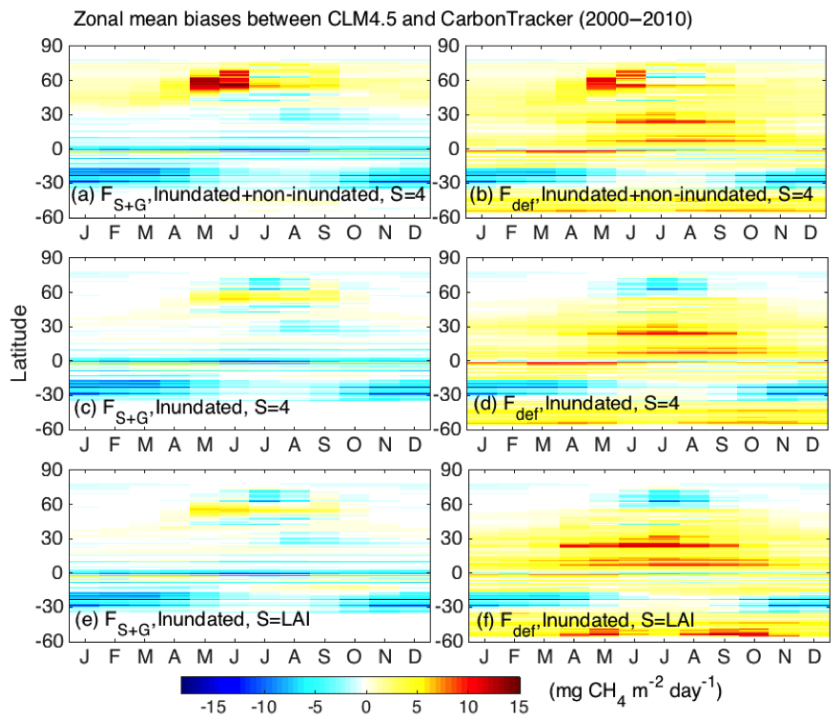

Figure 1. Zonal mean biases of $\mathrm{CH}_{4}$ emissions between CLM4.5 predictions and CarbonTracker ( $\mathrm{CH}_{4}$ CLM4.5$\mathrm{CH}_{4}$ CarbonTracker) with SWAMPS-GLWD $\left(F_{S+G}\right)$ and CLM4.5 predicted $\left(F_{\text {def }}\right)$ inundation fraction: CLM4.5 predictions of both inundated and non-inundated emissions with $F_{S+G}$ (a) and $F_{\text {def }}($ b), while aerenchyma area is corrected with $S=4$ CLM4.5 predictions of inundated emissions only with $F_{S+G}$ (c) and $F_{\text {def }}($ d), while aerenchyma area is corrected with $S=4$; CLM4.5 predictions of inundated emissions only with $F_{S+G}$ (e) and $F_{\text {def }}(\mathbf{f})$, while aerenchyma area is parameterized by default $S=$ LAI

tion rate also occurs when aerenchyma area is calculated with $\mathrm{C}_{\mathrm{FR}}$.

The uncertainty in representing the seasonality of aerenchyma area is due to (1) a poor current understanding of root dynamics and their control on aerenchyma area and (2) scant relevant observations. In tundra, the aboveground production is often not a good proxy for belowground production because the soil temperature peaks later in the growing season than solar irradiance (Sullivan and Welker, 2005; Sloan, 2011). Further, root dynamics are strongly species dependent. Root growth of Eriophorum angustifolium may not be delayed when soil temperature is near $0{ }^{\circ} \mathrm{C}$ (Chapin, 1974; Billing et al., 1977), while Dupontia fischeri produces many fewer root tips at these low temperatures. In Eriophorum vaginatum, fine-root growth lags significantly behind the aboveground spring growth flush (Kummerow and Russell, 1980).

To eliminate the possible bias in the seasonal variation of roots and the extremely low oxidation rate which caused CLM4.5 to predict a large $\mathrm{CH}_{4}$ burst from inundated areas during the spring thaw, we modified the model parameter $S$ to be constant, which is used in the aerenchyma area estimation. We constrained $S$ using global total $\mathrm{CH}_{4}$ emissions estimated by top-down and bottom-up simulations during 

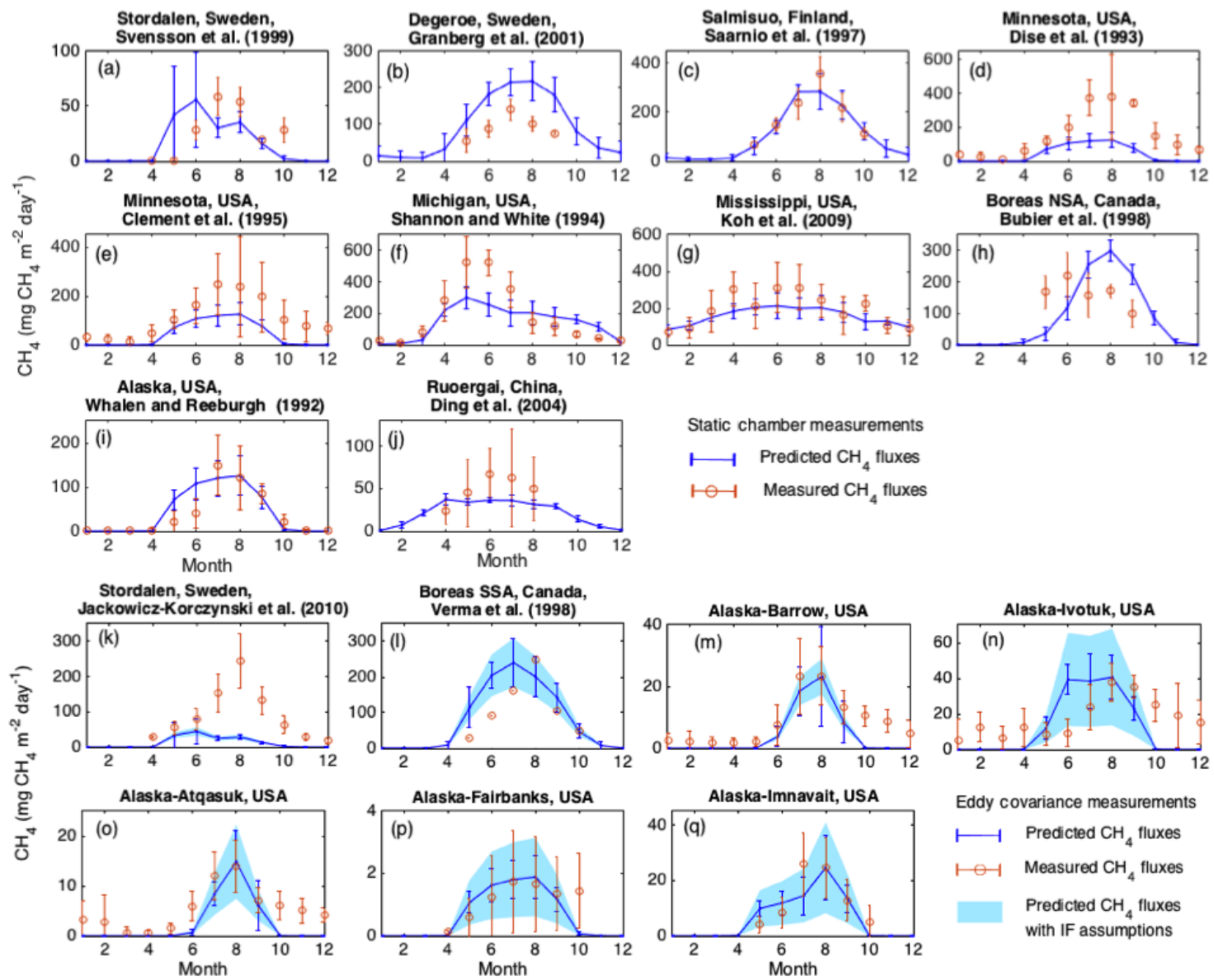

Eddy covariance measurements

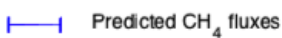

$\vdash-1$ Measured $\mathrm{CH}_{4}$ fluxes

Predicted $\mathrm{CH}_{4}$ fluxes with IF assumptions

Figure 2. Comparison of monthly mean simulated net $\mathrm{CH}_{4}$ flux between 2000 and 2012 and observed monthly mean net $\mathrm{CH}_{4}$ emissions in measurement year(s). The site measurements with static chamber are shown in (a)-(j), and measurements with eddy covariance (EC) towers are shown in (k)-(q). The error bars are standard deviation of monthly mean. The measurements with EC tower are weighted with a range of inundation fraction (IF) based on best estimates available: Stordalen - 80-100\%; Boreas SSA - 50-90\%; Alaska-Barrow - 60-100 \%; Alaska-Atqasuk - 10-30\%; Alaska-Ivotuk - 5-25\%; Alaska-Fairbanks - 0.5-2.5\%; Alaska-IMN - 5-25\%. Detailed description of the sites and measurements are shown in Table $\mathrm{S} 1$.

2000-2009 (Kirschke et al., 2013) and site-level measurements. We exclude the $\mathrm{CH}_{4}$ emission from non-inundated areas for the analysis of seasonal dynamics because the model shows a very small seasonal contribution of $\mathrm{CH}_{4}$ emissions from non-inundated areas globally (Fig. 1). This $\mathrm{CH}_{4}$ emission pulse from non-inundated areas, which may be related to soil moisture anomalies during spring thaw, has not been experimentally validated but can lead to large biases in simulated $\mathrm{CH}_{4}$ emissions from northern high latitudes $\left(>50^{\circ} \mathrm{N}\right)$ in May and June (Fig. 1a and b). This simplification of the model-produced seasonal cycles that did not contain the large springtime $\mathrm{CH}_{4}$ emission bursts, and we therefore used this modified version for all experiments here.

We assessed the sensitivity of the modeled $\mathrm{CH}_{4}$ fluxes to parametric uncertainty in the constant dimensionless factor $S$, as described above. $S$ has a direct effect on the magnitude of modeled $\mathrm{CH}_{4}$ emissions via its control of oxygen diffusion through the soil column and thus $\mathrm{CH}_{4}$ oxidation. When $S=\mathrm{LAI}$, the very low LAI in the spring thaw period leads to low oxidation and consequently overestimated $\mathrm{CH}_{4}$ net emissions compared to CarbonTracker predictions. During the growing season, the model overestimates LAI at high latitude (Tian et al., 2004) leading to high oxidation and consequently underestimated net $\mathrm{CH}_{4}$ emissions (Fig. 1e and f). However, few observations of aerenchymous tissue biomass are available to provide an a priori constraint to this value. Our goal here is to use a reasonable value of this parameter, not to fully characterize the uncertainty of the parameter choice on $\mathrm{CH}_{4}$ emissions.

Based on a comparison of the globally integrated $\mathrm{CH}_{4}$ flux with other global estimates, we choose $S=4$, which resulted in an estimated annual total $\mathrm{CH}_{4}$ emission of 228 (interannual variability (IAV): $221-239) \mathrm{Tg} \mathrm{CH}_{4} \mathrm{yr}^{-1}$ with $F_{\text {def }}$ and 206 (IAV: 200-217) $\mathrm{Tg} \mathrm{CH}_{4} \mathrm{yr}^{-1}$ with $F_{S+G}$ dur- 


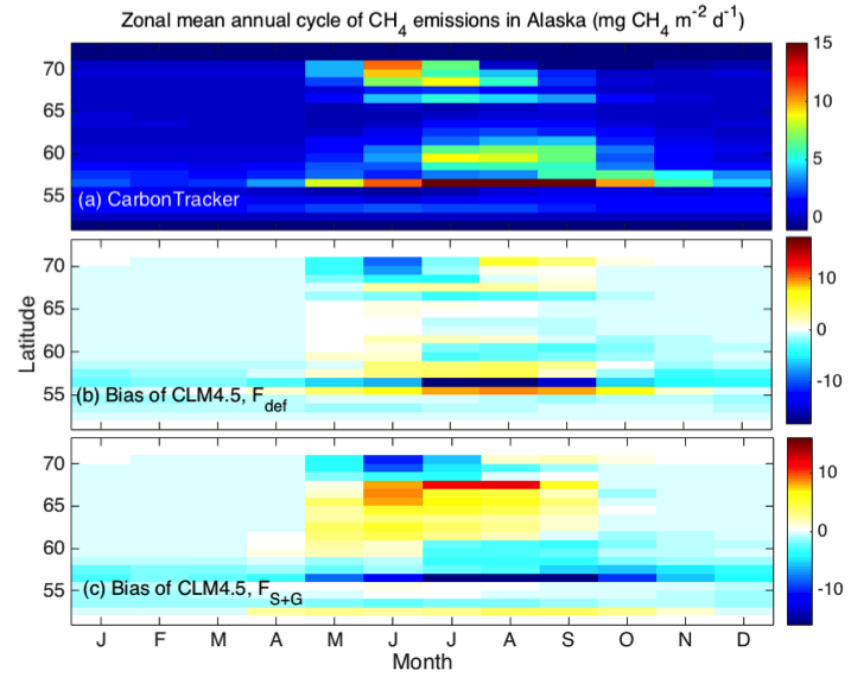

Figure 3. The 2000-2010 zonal mean annual cycle of $\mathrm{CH}_{4}$ emission ( $\mathrm{mg} \mathrm{CH}_{4} \mathrm{~m}^{-2} \mathrm{day}^{-1}$ ) across Alaska predicted by CarbonTracker (a) and biases of CLM4.5 with CLM4.5-predicted inundation fraction $\left(F_{\mathrm{def}}\right)(\mathbf{b})$ and SWAMPS-GLWD inundation fraction $\left(F_{S+G} ; \mathbf{c}\right)$. The $0.5^{\circ} \times 0.5^{\circ} \mathrm{CLM} 4.5$ is regridded to $1^{\circ} \times 1^{\circ}$ to be consistent with CarbonTracker.

ing the period 2000-2009. The top-down and bottom-up models provide estimates of $\mathrm{CH}_{4}$ emissions from natural wetlands of 175 (IAV: 142-208) $\mathrm{Tg} \mathrm{CH}_{4} \mathrm{yr}^{-1}$ and 217 (IAV: 177-284) $\mathrm{Tg} \mathrm{CH}_{4} \mathrm{yr}^{-1}$, respectively, during the same period (Kirschke et al., 2013). The mean $\mathrm{CH}_{4}$ emission predicted by CLM4.5 is about $42 \mathrm{Tg} \mathrm{CH}_{4} \mathrm{yr}^{-1}$ lower than the original CLM4Me prediction (annual mean of $270 \mathrm{Tg} \mathrm{CH}_{4} \mathrm{yr}^{-1}$ from 1948 to 1972) but slightly larger than the mean value from other bottom-up and top-down models. The disagreement between studies with different models is as large as $66 \%$ (Kirschke et al., 2013); hence, our estimate is well within the range of values from top-down constraints and underscores the uncertainty involved in using such a constraint in inferring model parameters.

Compared with CarbonTracker predictions, CLM's biases of underestimated growing season $\mathrm{CH}_{4}$ emissions north of $56^{\circ} \mathrm{N}$ and biases of overestimated $\mathrm{CH}_{4}$ emissions in 2$53^{\circ} \mathrm{N}$ and $34-56^{\circ} \mathrm{S}$ are reduced when using $S=4$ compared to the default parameterization (Fig. 1d and f). For the global zonal mean, the $\mathrm{CLM} \mathrm{CH}_{4}$ prediction biases are reduced with $F_{S+G}\left(\mathrm{RMSE}=2.5 \mathrm{mg} \mathrm{CH}_{4} \mathrm{~m}^{-2}\right.$ day $\left.^{-1}\right)$ compared with $F_{\text {def }}\left(\mathrm{RMSE}=3.1 \mathrm{mg} \mathrm{CH}_{4} \mathrm{~m}^{-2} \mathrm{day}^{-1}\right)$. With $F_{S+G}$, the biases are much reduced in $2-50^{\circ} \mathrm{N}$ and 30 $58^{\circ} \mathrm{S}$. However, negative $\mathrm{CH}_{4}$ emission biases in the tropics remain (Fig. 1c and e). The differences in $\mathrm{CH}_{4}$ emissions using SWAMPS-GLWD and CLM4.5-predicted inundation fraction implies that the prediction uncertainties are not only from the biogeochemical parameterization but also from the wetland extent, consistent with several recent model intercomparison analyses (Melton et al., 2013; Bohn
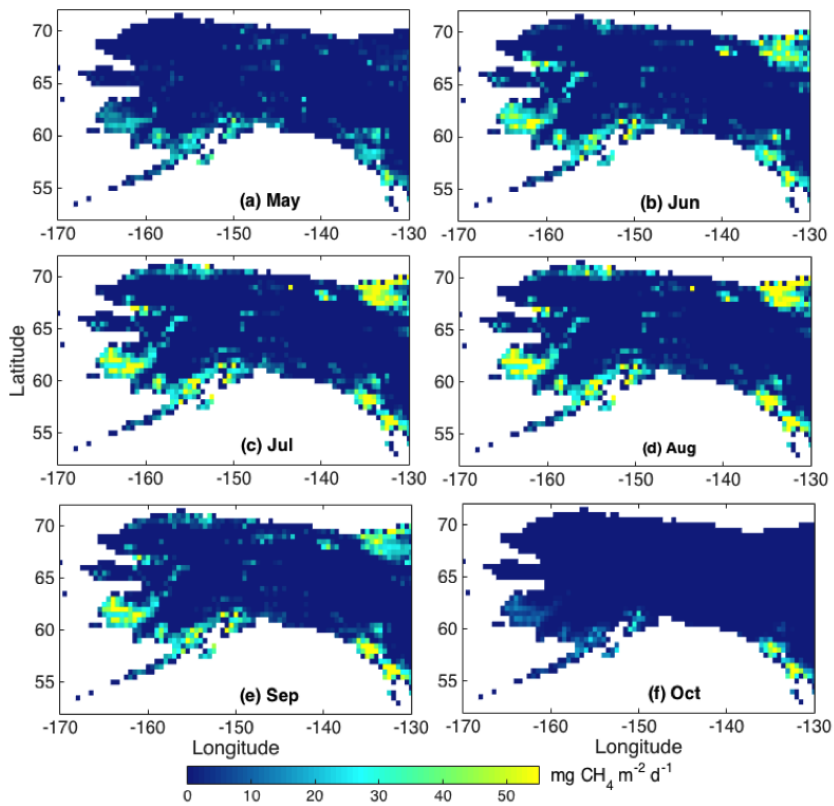

Figure 4. CLM4.5 simulated mean monthly $\mathrm{CH}_{4}$ emissions with $F_{\text {def }}$ across years 2000-2012.

et al., 2015). In Alaska, the predicted annual $\mathrm{CH}_{4}$ emissions between 2000 and 2010 are $1.47 \pm 0.20,1.58 \pm 0.07$ and $1.12 \pm 0.05 \mathrm{Tg} \mathrm{CH}_{4} \mathrm{yr}^{-1}$ for CarbonTracker, CLM4.5 with $F_{S+G}$ and CLM4.5 with $F_{\text {def }}$, respectively. Although our predicted annual emissions are reasonable compared with most land surface model predictions, the May to September predictions are about $50-70 \%$ of the emissions estimated using an atmospheric inversion based on CARVE observations of $2.1 \pm 0.5 \mathrm{Tg}, \mathrm{CH}_{4} \mathrm{yr}^{-1}$ (Chang et al., 2014).

\subsection{Seasonal $\mathrm{CH}_{4}$ emissions}

\subsubsection{Site-level comparison}

The mean seasonal cycle of predicted $\mathrm{CH}_{4}$ emissions is calculated from the $2000-2012$ monthly mean in a $0.5^{\circ} \times 0.5^{\circ}$ grid cell where site measurements exist, while the seasonal cycle of site measurements is calculated for the measurement years. If multiple measurement sites and multiple measurement years with the same measurement method (SC or EC) exist within a given grid cell, the observations are averaged to create a grid cell mean value that can be directly compared with the modeled value for that grid cell. In the 10 site-level static-chamber measurements at saturated sites (Fig. 2a-1), the seasonality is well predicted by the revised CLM4.5 $\mathrm{CH}_{4}$ model at most sites. Measurements and predictions show the peak emission month to be July or August at most sites, except the site in Michigan, USA (Fig. 2f), where the model successfully predicted the peak emissions in May. However, the model misrepresents the seasonality at the Stordalen (Sweden; Fig. 2a and k) and the Boreas NSA 
(northern study area) (Canada; Fig. 2i) site. At the Ruoergai site (China; Fig. 2j), the model does not show a strong seasonal variation from April to September and notably underestimates the growing season $\mathrm{CH}_{4}$ emissions. The underestimation of growing season emissions is also found at the Minnesota (USA), Michigan (USA) and Boreas NSA (Canada) sites (Fig. 2d, e, f and h). The sites experiencing soil frost with valid measurements in the cold season demonstrate the CLM4.5 underestimation of $\mathrm{CH}_{4}$ emissions during this period (Fig. 2a, d, e and i).

The eddy covariance measurements from four sites - the BEO1, BEO2, BES and CMDL sites - are in the same model grid cell; therefore, the measurements in these four sites are aggregated to the same grid cell as that of Alaska (Fig. 2m). As the footprints of the measurement towers were not estimated, all the modeled $\mathrm{CH}_{4}$ emissions at eddy covariance sites are weighted with an observationally estimated seasonally invariant range of inundation faction: Stordalen - 80$100 \%$; Boreas SSA (southern study area) - 50-90\%; Barrow - 60-100\%; Atqasuk - 10-30\%; Ivotuk - 5-25\%; Fairbanks $-0.5-2.5 \%$; and IMN $-5-25 \%$. Measurements at the Stordalen site (Fig. 2a and k) show very different $\mathrm{CH}_{4}$ emission patterns in seasonality and magnitude for different years and measurement methods. The model significantly underestimates $\mathrm{CH}_{4}$ emissions even with the maximum fraction of inundation in Stordalen (Fig. 2k). In comparison with the static-chamber measurements at Alaska (Fig. 2h), the model predicts a much shorter $\mathrm{CH}_{4}$ emission season at the noninundated sites (Fig. $2 \mathrm{~m}-\mathrm{q}$ ). The estimated $\mathrm{CH}_{4}$ emissions begin in April at Ivotuk, Fairbanks and Imnavait. At the northern sites, Barrow and Atqasuk, the estimated $\mathrm{CH}_{4}$ emissions begin in May. In the short emission season, the model underestimates $\mathrm{CH}_{4}$ emissions in June and July at Barrow and Atqasuk and in July at Imnavait, even with the maximum inundation estimation. While the cold-season measurements at Barrow, Atqasuk and Ivotuk show large $\mathrm{CH}_{4}$ emissions from October to April in agreement with the static-chamber measurements at the sites with cold-season soil frost, predicted $\mathrm{CH}_{4}$ emissions end in October at all the Alaskan sites. The largest monthly mean emissions in Alaska cold season are $24.8 \pm 9.0 \mathrm{mg} \mathrm{CH}_{4} \mathrm{~m}^{-2} \mathrm{day}^{-1}$ measured in October at Ivotuk.

A number of factors affect the correspondence between site-level $\mathrm{CH}_{4}$ emission observations and CLM4.5 predictions (Fig. 2), including (1) that we used reanalysis climate forcing data which may lead to some of the differences with the site observations; (2) that we used the model's default surface characterization, which is unlikely to exactly match the actual vegetation and soil properties; (3) that the spatial and temporal coverage of the site data are sparse; (4) that the interannual variation of wetland $\mathrm{CH}_{4}$ emission can be significant; (5) that the method of measuring $\mathrm{CH}_{4}$ fluxes varied from site to site and (6) that the seasonal fraction of inundation in the eddy covariance tower footprint is unknown. We also expect differences between our CLM4.5 predictions
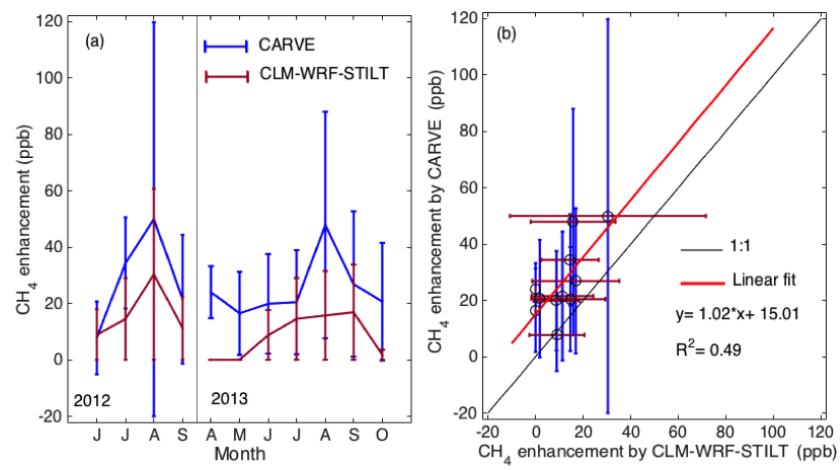

Figure 5. The monthly mean atmospheric mole fraction enhancements in $\mathrm{CH}_{4}$ estimated by WRF-STILT-CLM4.5 and CARVE measurements. (a) Observed and simulated monthly $\mathrm{CH}_{4}$ mole fraction enhancements in 2012 and 2013; (b) linear regression of measured versus modeled $\mathrm{CH}_{4}$ mole fraction enhancements. The error bars are standard deviation of monthly mean.

and those reported in Riley et al. (2011) at the site-level comparison because (1) simulations in this study were done at a higher resolution $\left(0.5^{\circ} \times 0.5^{\circ}\right)$ than those in Riley et al. $\left(2011 ; 1.9^{\circ} \times 2.5^{\circ}\right)$; (2) the current simulations are forced by CRUNCEP climate, while Riley et al. (2011) simulations were forced with Qian et al. (2006) climate; (3) the $S$ parameter is changed, as discussed above; and (4) the overall water and carbon cycles of CLM changed substantially between CLM4.0 and CLM4.5 (Koven et al., 2013). The sitelevel discrepancies occur because of the uncertainties discussed above and those arising from other parameters (Riley et al., 2011), including $Q_{10}$ of $\mathrm{CH}_{4}$ production and oxidation, the $\mathrm{CH}_{4}$ half-saturation oxidation coefficient, the $\mathrm{O}_{2}$ halfsaturation oxidation coefficient, maximum oxidation rate of $\mathrm{CH}_{4}$ oxidation and the impact of $\mathrm{pH}$ and redox potential on $\mathrm{CH}_{4}$ production.

\subsubsection{Regional $\mathrm{CH}_{4}$ emissions comparison}

The biases between CLM4.5 and CarbonTracker $\mathrm{CH}_{4}$ emissions vary with latitude (Fig. 3). The aggregated $F_{S+G}$ led to larger $\mathrm{CH}_{4}$ emission biases in Alaska (RMSE $=4 \mathrm{mg} \mathrm{CH}_{4} \mathrm{~m}^{-2}$ day $^{-1}$ ) compared to the $\mathrm{CH}_{4}$ prediction with $F_{\text {def }}\left(\mathrm{RMSE}=3 \mathrm{mg} \mathrm{CH}_{4} \mathrm{~m}^{-2}\right.$ day $^{-1}$ ), although it led to smaller global $\mathrm{CH}_{4}$ emission biases. In Alaska between 58 and $66^{\circ} \mathrm{N}$ during the growing season, CLM4.5 using $F_{\text {def }}$ has good agreement with CarbonTracker predictions. In this region, $\mathrm{CH}_{4}$ emissions begin in May, peak in July and August, and end in October (Fig. 4). In May and June, CarbonTracker shows a weak $\mathrm{CH}_{4}$ sink $\left(\sim \mathrm{O}\left[10^{-2}\right.\right.$ $\left.10^{-1}\right] \mathrm{mg} \mathrm{CH}_{4} \mathrm{~m}^{-2}$ day $\left.^{1}\right)$ in contrast to a CLM4.5-predicted weak $\mathrm{CH}_{4}$ source $\left(\sim \mathrm{O}\left[10^{-1}\right] \mathrm{mg} \mathrm{CH}_{4} \mathrm{~m}^{-2}\right.$ day $\left.^{-1}\right)$ with $F_{\text {def }}$ and stronger $\mathrm{CH}_{4}$ source $\left(\sim \mathrm{O}[1] \mathrm{mg} \mathrm{CH}_{4} \mathrm{~m}^{-2}\right.$ day $\left.^{-1}\right)$ with $F_{S+G}$ in the interior region of Alaska (Interior Alaska) between 63 and $66^{\circ} \mathrm{N}$. We hypothesize that this discrep- 


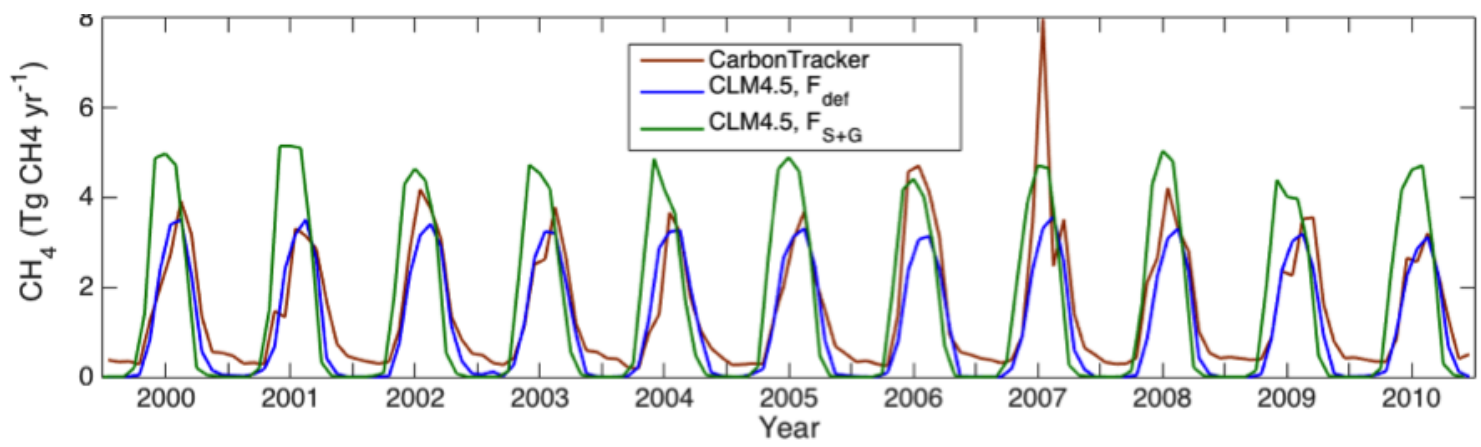

Figure 6. Time variation of integrated $\mathrm{CH}_{4}\left(\mathrm{Tg} \mathrm{CH}_{4} \mathrm{yr}^{-1}\right)$ emissions from Alaska by CarbonTracker (brown), CLM4.5 with internally predicted fraction of inundation $F_{\text {def }}$ (blue) and CLM4.5 SWAMPS-GLWD fraction of inundation $F_{\mathrm{S}+\mathrm{G}}$ (green).

ancy occurs because of the difference in the two wetland datasets and the accounting of $\mathrm{CH}_{4}$ emissions from the noninundated areas in CarbonTracker. $\mathrm{Net}^{\mathrm{CH}_{4}}$ consumption occurs at dry sites where oxygen is available in the topsoil layers (Wickland et al., 1999); however, $\mathrm{CH}_{4}$ fluxes from the non-inundated, areas which could be substantial (Zona et al., 2016), are excluded in CLM4.5 predictions shown in Fig. 3, as described in the "Methods" section. Interior Alaska has a highly continental climate with warm and relatively dry summers and extremely cold winters. The weak $\mathrm{CH}_{4}$ source in the dry summer is thus caused by a reduced wetland extent in Interior Alaska. Interior Alaska experiences the most rain events in autumn, mainly in August and September (Hinzman et al., 2006), which restores some of the extent of wetlands and leads to increases in $\mathrm{CH}_{4}$ emissions in August and early September. CarbonTracker successfully represented the restored wetland in August and September but not CLM4.5 (Figs. 3 and 4). The autumn emission period is very short and ends with the onset of winter, resulting in a strong drop in $\mathrm{CH}_{4}$ emissions in October.

The CLM4.5 underestimation of northern $\left(>68^{\circ} \mathrm{N}\right)$ Alaska site-level $\mathrm{CH}_{4}$ emissions during the growing season at some sites is confirmed with comparison to CarbonTracker inversions (Fig. 3b). In southern and northern coastal Alaska, CLM4.5 predicts a much shorter $\mathrm{CH}_{4}$ emission season and a smaller magnitude of $\mathrm{CH}_{4}$ emissions than CarbonTracker. The period of the largest underestimation by CLM4.5 is from May to July, with the maximum underestimation of about $9.2 \mathrm{mg} \mathrm{CH}_{4} \mathrm{~m}^{-2} \mathrm{day}^{-1}$ in June. The underestimated $\mathrm{CH}_{4}$ emissions occur with both $F_{S+G}$ and $F_{\text {def }}$ in the north of $68^{\circ} \mathrm{N}$. During the cold season from October to April, CLM4.5 predictions with $F_{S+G}$ or $F_{\text {def }}$ are consistently smaller than CarbonTracker estimates across all the latitudes. The mean underestimation of cold-season $\mathrm{CH}_{4}$ emission is less than $1 \mathrm{mg} \mathrm{CH}_{4} \mathrm{~m}^{-2}$ day $^{-1}$, which is much smaller than the underestimation we found compared to site-level measurements. In comparison with CarbonTracker, CLM4.5 predicted $0.46 \pm 0.07$ and $0.39 \pm 0.08 \mathrm{Tg}$ less Alaska-wide $\mathrm{CH}_{4}$ emissions in the cold season (October to April) with $F_{S+G}$ and $F_{\text {def }}$, respectively.

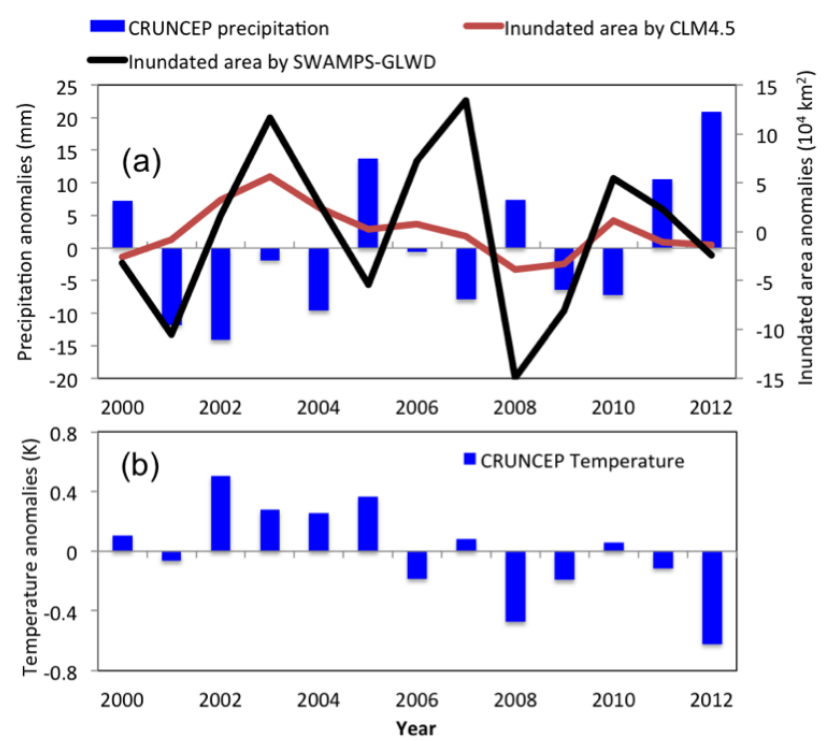

Figure 7. The anomalies of annual precipitation and inundated area in Alaska (a) and the anomalies of annual mean temperature (b). The anomalies are calculated by subtracting the average between 2000 and 2012.

The CarbonTracker inversions suggest that $21.9 \pm 3.2 \%$ of the annual Alaska $\mathrm{CH}_{4}$ emissions occur during the cold season, while CLM4.5 predicts that only $3.5 \pm 1.3$ and $8.3 \pm 3.0 \%$ (with $F_{\text {def }}$ and $F_{S+G}$, respectively) occur during the cold season. When September and April are included in the "cold season", the contribution is increased to $45.3 \pm 4.5 \%$ by CarbonTracker, which is slightly smaller than the cold-season contribution $(50 \pm 9 \%)$ inferred from site-level (BEO2, BES, CMDL, ATQ and IVO) measurements (Zona et al., 2016). The September-April contributions to annual emissions predicted by CLM4.5 are $32.1 \pm 8.1$ and $40.1 \pm 14.7 \%$ of the predicted annual emissions with $F_{S+G}$ and $F_{\text {def }}$, respectively. Although $\mathrm{CH}_{4}$ fluxes from the ocean surface are excluded, we cannot exclude some influence of coastal grid cells on the CarbonTracker estimates. 

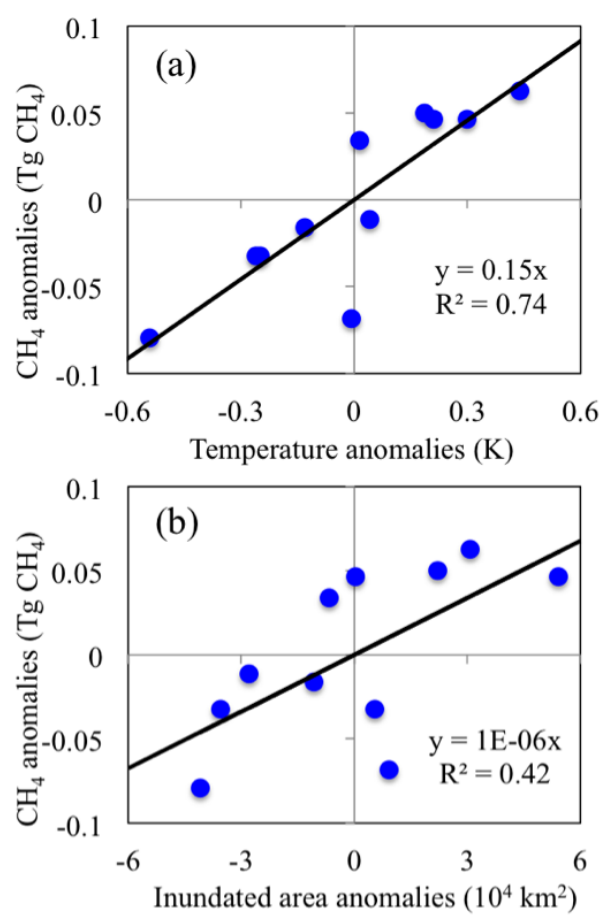

Figure 8. The correlation between CLM-predicted annual $\mathrm{CH}_{4}$ emission anomalies and mean annual temperature anomalies (a) and correlation between annual $\mathrm{CH}_{4}$ emission anomalies and predicted inundated area anomalies during 2000-2010. The anomalies are calculated by subtracting the average between 2000 and 2010 .

The atmospheric $\mathrm{CH}_{4}$ mole fraction enhancements calculated from CLM4.5-predicted $\mathrm{CH}_{4}$ emissions are lower than the CARVE-measured $\mathrm{CH}_{4}$ mole fraction enhancements (Fig. 5). However, in contrast to the emission underestimations that only occur from May to July, the monthly atmospheric $\mathrm{CH}_{4}$ mole fraction enhancements are underestimated throughout the year, with a maximum underestimation in $\mathrm{Au}-$ gust (Fig. 5a). The CARVE-measured peak mole fraction enhancement due to surface $\mathrm{CH}_{4}$ emissions is in August for both 2012 and 2013. Although CLM4.5 predicted the peak $\mathrm{CH}_{4}$ mole fraction enhancement in August 2012, predicted seasonal $\mathrm{CH}_{4}$ mole fraction enhancements are much smaller in 2013 and peaks in September. The underestimation of cold-season mole fraction $\mathrm{CH}_{4}$ enhancements by CLM4.5 leads to $24.0 \pm 9.2$ and $18.9 \pm 17.3$ ppb lower $\mathrm{CH}_{4}$ mole fraction enhancements in April and October 2013, respectively. From April to October, the 2-year mean monthly atmospheric $\mathrm{CH}_{4}$ mole fraction enhancements are underestimated by 15 ppb in WRF-STILT-CLM model predictions. The underestimation may not be attributed to anthropogenic $\mathrm{CH}_{4}$ source and agricultural waste because (1) we excluded both observed and modeled $\mathrm{CH}_{4}$ mole fraction enhancements when $[\mathrm{CO}]>150 \mathrm{ppb}$, given that anthropogenic $\mathrm{CH}_{4}$ mole fraction enhancements are consistently correlated to $\mathrm{CO}$ mole fraction enhancements (Zona et al., 2016), and (2) the $\mathrm{CH}_{4}$ emissions from agricultural waste does not show strong seasonal variation according to CarbonTracker estimates. The large standard deviation of CARVE-observed $\mathrm{CH}_{4}$ mole fraction enhancements implies that the $\mathrm{CH}_{4}$ emissions have large spatial and temporal variability. The CLM4.5 predictions are generally within the observed range of variation except in April and May in 2013.

The very low cold-season $\mathrm{CH}_{4}$ emission predictions on site and regional scales occur because of the assumed temperature sensitivity for $\mathrm{CH}_{4}$ production when the soil temperature of a given layer is at or below freezing (i.e., no $\mathrm{CH}_{4}$ production occurs in that soil layer). The multilayer structure of CLM4.5 can in principle generate $\mathrm{CH}_{4}$ emissions deeper in the soil after the surface has frozen, though even then, modeled diffusion rates through frozen surface layers are low. Although the measurements show winter $\mathrm{CH}_{4}$ emissions, it remains uncertain whether these emissions are from production at low temperature or residual $\mathrm{CH}_{4}$ from the end of the growing season. Understanding which of these is occurring is important for diagnosing how to improve model representation of the processes responsible for the wintertime fluxes. The cold-season underestimation by CLM4.5 is also partly attributed to the low wetland area during this period at high latitudes (currently, $F_{\text {def }}$ is set to zero when snow is present). Given the current observations of $\mathrm{CH}_{4}$ emissions during the cold season, we believe these two factors need to be reevaluated in CLM4.5.

\subsection{Interannual variation of $\mathrm{CH}_{4}$ cycle}

The CLM4.5 simulated Alaska $\mathrm{CH}_{4}$ emissions using $F_{\text {def }}$ are in very good agreement with CarbonTracker- $\mathrm{CH}_{4}$ emission in the growing season but biased in the cold season (Fig. 6). The largest growing season discrepancies occur in 2006 and 2007. Bruhwiler et al. (2014) attributed the CarbonTracker $2007 \mathrm{CH}_{4}$ emission anomaly to warmer temperatures and higher than normal precipitation. However, the CRUNCEP reanalysis data we used to force CLM4.5 do not have a positive precipitation anomaly in either 2006 or 2007 (Fig. 7a). In contrast, there is a strong negative precipitation anomaly in 2007. The obvious wet years (2000, 2005, 2008, 2011 and 2012) in the CRUNCEP reanalysis data are not directly related to the predicted and measured wetland area anomaly or $\mathrm{CH}_{4}$ emission anomaly. The mean air temperature in 2007 is only slightly higher than 2000-2012 mean air temperature (Fig. 7b). The correlation analysis implies that the model-predicted interannual $\mathrm{CH}_{4}$ variation is mainly explained by temperature variation (Fig. $8 \mathrm{a} ; r=0.86, P=0.0007$ ), followed by the default wetland extent $\left(F_{\mathrm{def}}\right)$ variation (Fig. $8 \mathrm{~b} ; r=0.65, P=0.03$ ), but weakly explained by SWAMPS-GLWD wetland extent $\left(F_{S+G}\right)$ variation $(r=0.44, P=0.17)$ and precipitation variation $(r=0.18, P=0.58)$. When the $\mathrm{CH}_{4}$ predictions are calculated with $F_{S+G}$, correlation between the interannual variation of $\mathrm{CH}_{4}$ and variation in $F_{S+G}(r=0.18$, 
$P=0.59)$, precipitation $(r=0.36, P=0.29)$ and temperature $(r=0.32, P=0.33)$ are substantially reduced. Interannual variation of $\mathrm{CH}_{4}$ emissions by CarbonTracker are not well correlated to SWAMPS-GLWD wetland extent variation $(\mathrm{r}=0.33, \mathrm{P}=0.32)$, variations in CRUNCEP temperature $(r=-0.23, P=0.49)$ or precipitation $(r=-0.06$, $P=0.86)$.

\section{Concluding remarks}

We implemented and tested needed changes to the estimate of aerenchyma area in CLM4.5. The modeled and measured $\mathrm{CH}_{4}$ emissions and enhancements in atmospheric mole fractions of $\mathrm{CH}_{4}$ are used to analyze the seasonal wetland $\mathrm{CH}_{4}$ emission cycle in Alaska. Both the measurements and model predictions show large latitudinal variability of $\mathrm{CH}_{4}$ seasonal cycles. At the site level, CLM4.5 generally captures the seasonality in growing season $\mathrm{CH}_{4}$ emissions. However, comparing eddy covariance $\mathrm{CH}_{4}$ observations with the model predictions is complicated by the unknown fraction of inundation in the footprint of the measurement tower, which may cause large variations in $\mathrm{CH}_{4}$ emission predictions. Measurements from the sites experiencing wintertime soil frost imply that $\mathrm{CH}_{4}$ emissions continue in the cold season (October to April). The likely incorrect treatment of $\mathrm{CH}_{4}$ production under soil frost in CLM4.5 leads to underestimates of the wintertime emissions. This conclusion is confirmed by the discrepancies between CLM4.5 and CarbonTracker predictions, although the cold-season discrepancies between CLM4.5 and CarbonTracker are much smaller than the discrepancies between CLM4.5 and site-level measurements. The differences between the seasonality predicted by CLM4.5 and CarbonTracker vary with time and latitude, although the Alaska area-integrated $\mathrm{CH}_{4}$ emissions agree well. Besides the strength of wintertime $\mathrm{CH}_{4}$ emissions, the main discrepancies between CLM4.5 and CarbonTracker estimates are northern and southern coastal area $\mathrm{CH}_{4}$ emissions. The inundation area leads to uncertainties in predictions of seasonal and interannual variability of $\mathrm{CH}_{4}$ emissions. Compared with the CLM4.5-predicted inundation area, the aggregated $F_{S+G}$ inundation led to smaller global $\mathrm{CH}_{4}$ emission biases than $F_{\text {def }}$ (RMSE dropped from 3.1 to $2.5 \mathrm{mg} \mathrm{CH}_{4} \mathrm{~m}^{-2}$ day $^{-1}$ ) between CLM4.5 and CarbonTracker. In contrast, the $F_{S+G}$ inundation area increased seasonal emission biases in Alaska by increasing RMSE from 3 to $4 \mathrm{mg} \mathrm{CH}_{4} \mathrm{~m}^{-2} \mathrm{day}^{-1}$ compared with the CLM4.5-predicted inundation. The larger SWAMPS-GLWD inundation area leads to much stronger Alaska-wide annual $\mathrm{CH}_{4}$ emissions compared to those calculated from the default predicted inundation area. CLM4.5 predictions show that the interannual variations of $\mathrm{CH}_{4}$ emissions are correlated with the reanalysis air temperature and wetland extent variation. In contrast, interannual variation in CarbonTracker $\mathrm{CH}_{4}$ emissions is weakly related to interan- nual variation in SWAMPS-GLWD wetland area and reanalysis precipitation and temperature.

The CLM4.5 $\mathrm{CH}_{4}$ module constrained from global total annual $\mathrm{CH}_{4}$ emissions does not accurately represent the seasonal cycles in the regional- and site-scale seasonal cycles due to large temporal and spatial heterogeneity in surface $\mathrm{CH}_{4}$ emissions and wetland extent. Further improving the $\mathrm{CH}_{4}$ biogeochemical model on the seasonal and annual timescales requires further extensive experiments to better understand climate controls on above- and belowground physiological processes and how vegetation controls gaseous transport (e.g., $\mathrm{CH}_{4}$ production under low temperatures). Although cold-season site-level measurements are rare, the large discrepancies in winter emissions between CLM4.5 and CarbonTracker predictions and site measurements indicate that studies on winter ecosystem activities and wetland evolution at high latitude would be valuable.

\section{Data availability}

The CLM4.5 model is released in CESM1.2.2 package available at http://www.cesm.ucar.edu/models/cesm1.2/tags/ index.html\#CESM1_2_2. The model outputs of $\mathrm{CH}_{4}$ emission and the fraction of inundation during 2000-2012 are available upon request to the corresponding author.

The site measurement data are available from the publications or the principle investigators provided in the Supplement.

The NOAA CarbonTracker-CH4 data assimilation product is available at http://www.esrl.noaa.gov/gmd/ccgg/ carbontracker-ch4/.

The CARVE flight data of $\mathrm{CH}_{4}$ measurements in 2012 and 2013 are available at https://ilma.jpl.nasa.gov/portal/.

The forcing CRU-NCEP v5 data are available at http://esgf.extra.cea.fr/thredds/fileServer/store/p529viov/ cruncep/readme.htm.

\section{The Supplement related to this article is available online at doi:10.5194/bg-13-5043-2016-supplement.}

Acknowledgements. Funding for this study was provided by the US Department of Energy, BER, under the RGCM program and NGEEArctic project under contract no. DE-AC02-05CH11231. We thank the CARVE flight group for their efforts on CARVE science flights. CarbonTracker $\mathrm{CH}_{4}$ results provided by NOAA ESRL, Boulder, Colorado, USA, from the website at http://www.esrl.noaa.gov. The eddy covariance tower data used in this study were supported by the Division of Polar Programs of the National Science Foundation (NSF; Award 1204263); Carbon in Arctic Reservoirs Vulnerability Experiment (CARVE), an Earth Ventures (EV-1) investigation, under contract with the National Aeronautics and Space Administration; and Department of Energy (DOE) Grant 
DE-SC005160. Logistical support was funded by the NSF Division of Polar Programs.

Edited by: A. V. Eliseev

Reviewed by: two anonymous referees

\section{References}

Bartlett, K. B., Crill, P. M., Sass, R. L., Harriss, R. C., and Dise, N. B.: Methane emissions from tundra environments in the YukonKuskokwim delta, Alaska, J. Geophys. Res., 97, 16645-16660, 1992.

Bergamaschi, P., Frankenberg, C., Meirink, J. F., Krol, M., Villani, M. G., Houweling, S., Dentener, F., Dlugokencky, E. J., Miller, J. B., Gatti, L. V., Engel, A., and Levin, I.: Inverse modeling of global and regional $\mathrm{CH}_{4}$ emissions using SCIAMACHY satellite retrievals, J. Geophys. Res.-Atmos., 114, D22301, doi:10.1029/2009JD012287, 2009.

Billings, W. D., Peterson, K. M., Shaver, G. R., and Trent, A. W.: Root growth, respiration, and carbon dioxide evolution in an Arctic tundra soil, Arct. Alp. Res., 9, 129-137, 1977.

Bohn, T. J., Melton, J. R., Ito, A., Kleinen, T., Spahni, R., Stocker, B. D., Zhang, B., Zhu, X., Schroeder, R., Glagolev, M. V., Maksyutov, S., Brovkin, V., Chen, G., Denisov, S. N., Eliseev, A. V., Gallego-Sala, A., McDonald, K. C., Rawlins, M. A., Riley, W. J., Subin, Z. M., Tian, H., Zhuang, Q., and Kaplan, J. O.: WETCHIMP-WSL: intercomparison of wetland methane emissions models over West Siberia, Biogeosciences, 12, 3321-3349, doi:10.5194/bg-12-3321-2015, 2015.

Brouchkov, A., Fukuda, M., Tomita, F., Asano, K., and Tanaka, M.: Microbiology and gas emission at low temperatures: some field and experimental results, Töhoku Geophys. Journ., 36, 452-455, 2003.

Bruhwiler, L., Dlugokencky, E., Masarie, K., Ishizawa, M., Andrews, A., Miller, J., Sweeney, C., Tans, P., and Worthy, D.: CarbonTracker- $\mathrm{CH}_{4}$ : an assimilation system for estimating emissions of atmospheric methane, Atmos. Chem. Phys., 14, 82698293, doi:10.5194/acp-14-8269-2014, 2014.

Chan, K. M. and Wood, R.: The seasonal cycle of planetary boundary layer depth determined using COSMIC radio occultation data, J. Geophys. Res.-Atmos., 118, 12422-12434, doi:10.1002/2013JD020147, 2013.

Chang, R. Y. W, Miller, C. E., Dinardo, S. J., Karion, A., Sweeney, C., Daube, B., Henderson, J. M., Mountain, M. E., Eluszkiewicz, J., Miller, J. B., Bruhwiler, L. M. P., and Wofsy, S. C.: Methane emissions from Alaska in 2012 from CARVE airborne observations, P. Natl. Acad. Sci. USA, 111, 16694-16699, 2014.

Chapin, F. S.: Morphological and physiological mechanisms of temperature compensation in phosphate absorption along a latitudinal gradient, Ecology, 55, 1180-1198, 1974.

Clein, J. S. and Schimel, J. P.: Microbial activity of tundra and taiga soils at sub-zero temperatures, Soil. Biol. Biochem., 29, 12311234, 1995.

Comas, X., Slater, L., and Reeve, A.: Seasonal geophysical monitoring of biogenic gases in a northern peatland: implications for temporal and spatial variability in free phase gas production rates, J. Geophys. Res.-Biogeo., 113, G01012, doi:10.1029/2007JG000575, 2008.
Dunfield, P., Knowles, R., Dumont, R., and Moore, T. R.: Methane production and consumption in temperate and subarctic peat soils: Response to temperature and $\mathrm{pH}$, Soil Biol. Biochem., 25, 321-326, 1993.

Euskirchen, E. S., Bret-Harte, M. S., Scott, G. J., Edgar, C., and Shaver, G. R.: Seasonal patterns of carbon dioxide and water fluxes in three representative tundra ecosystems in northern Alaska, Ecosphere, 3, 1-19, 2012.

Hargreaves, K. J., Fowler, D., Pitcairn, C. E. R., and Aurela, M.: Annual methane emission from Finnish mires estimated from eddy covariance campaign measurements, Theor. Appl. Climatol. 70, 203-213, 2001.

Henderson, J. M., Eluszkiewicz, J., Mountain, M. E., Nehrkorn, T., Chang, R. Y.-W., Karion, A., Miller, J. B., Sweeney, C., Steiner, N., Wofsy, S. C., and Miller, C. E.: Atmospheric transport simulations in support of the Carbon in Arctic Reservoirs Vulnerability Experiment (CARVE), Atmos. Chem. Phys., 15, 4093-4116, doi:10.5194/acp-15-4093-2015, 2015.

Hinzman, L. D., Viereck, L. A., Adams, P., Romanovsky, V. E., and Yoshikawa, K.: Climate and permafrost dynamics of the Alaskan boreal forest, in: Alaska's changing boreal forest, edited by: Chapin III, F. S., Oswood, M. W., Van Cleve, K., Viereck, L. A., and Verbyla, D. L., Oxford University Press, New York, 39-61, 2006.

Hommeltenberg, J., Schmid, H. P., Drösler, M., and Werle, P.: Can a bog drained for forestry be a stronger carbon sink than a natural bog forest?, Biogeosciences, 11, 3477-3493, doi:10.5194/bg-113477-2014, 2014.

Hugelius, G., Strauss, J., Zubrzycki, S., Harden, J. W., Schuur, E. A. G., Ping, C.-L., Schirrmeister, L., Grosse, G., Michaelson, G. J., Koven, C. D., O’Donnell, J. A., Elberling, B., Mishra, U., Camill, P., Yu, Z., P almtag, J., and Kuhry, P.: Estimated stocks of circumpolar permafrost carbon with quantified uncertainty ranges and identified data gaps, Biogeosciences, 11, 65736593, doi:10.5194/bg-11-6573-2014, 2014.

Iversen, C. M., Sloan, V. L., Sullivan, P. F., Euskirchen, E. S., McGuire, A. D., Norby, R. J., Walker, A. P., Warren, J. M., and Wullschleger, S. D.: The unseen iceberg: plant roots in arctic tundra, New Phytol., 205, 34-59, doi:10.1111/nph.13003, 2015.

Iwata, H., Harazono, Y., Ueyama, M., Sakabe, A., Nagano, H., Kosugi, Y., Takahashi, K., and Kim, Y.: Methane exchange in a poorly-drained black spruce forest over permafrost observed using the eddy covariance technique, Agr. Forest Meteorol., 214215, 157-168, 2015.

Juutinen, S., Alm, J., Larmola, T., Huttunen, J. T., Morero, M., Martikainen, P. J., and Silvola, J.: Major implication of the littoral zone for methane release from boreal lakes, Global Biogeochem. Cy., 17, 1117, 10.1029/2003GB002105, 2003.

King, J. Y., William, S. R., and Shannon K. R.: Methane emission and transport by arctic sedges in Alaska: results of a vegetation removal experiment, J. Geophys. Res., 103, 29083-29092, 1998.

Kirschke, S., Bousquet, P., Ciais, P., Saunois, M., Canadell, J. G., Dlugokencky, E. J., Bergamaschi, P., Bergmann, D., Blake, D. R., Bruhwiler, L., Cameron Smith, P., Castaldi, S., Chevallier, F., Feng, L., Fraser, A., Heimann, M., Hodson, E. L., Houweling, S., Josse, B., Fraser, P. J., Krummel, P. B., Lamarque, J., Langenfelds, R. L., Le Quéré, C., Naik, V., O’Doherty, S., Palmer, P. I., Pison, I., Plummer, D., Poulter, B., Prinn, R. G., Rigby, M., Ringeval, B., Santini, M., Schmidt, M., Shindell, D. T., Simp- 
son, I. J., Spahni, R., Steele, L. P., Strode, S. A., Sudo, K. Szopa, S., van der Werf, G. R., Voulgarakis, A., van Weele, M., Weiss, R. F., Williams, J. E., and Zeng, G.: Three decades of global methane sources and sinks, Nat. Geosci., 6, 813-823, doi:10.1038/ngeo1955, 2013.

Koven, C. D., Riley, W. J., Subin, Z. M., Tang, J. Y., Torn, M. S., Collins, W. D., Bonan, G. B., Lawrence, D. M., and Swenson, S. C.: The effect of vertically resolved soil biogeochemistry and alternate soil $\mathrm{C}$ and $\mathrm{N}$ models on $\mathrm{C}$ dynamics of CLM4, Biogeosciences, 10, 7109-7131, doi:10.5194/bg-10-7109-2013, 2013.

Kummerow, J. and Russell, M.: Seasonal root growth in the Arctic tussock tundra, Oecologia, 47, 196-199, 1980.

Lehner, B. and Doll, P.: Development and validation of a global database of lakes, reservoirs and wetlands, J. Hydrol., 296, 1-22, 2004.

Lupascu, M., Wadham, J. L., Hornibrook, E. R. C., and Pancost, R. D.: Temperature sensitivity of methane production in the permafrost active layer at Stordalen, Sweden: A comparison with non-permafrost northern wetlands, Arct. Antarc. Alp. Res., 44, 469-482, 2012

Mastepanov, M., Sigsgaard, C., Tagesson, T., Ström, L., Tamstorf, M. P., Lund, M., and Christensen, T. R.: Revisiting factors controlling methane emissions from high-Arctic tundra, Biogeosciences, 10, 5139-5158, doi:10.5194/bg-10-5139-2013, 2013.

Mastepanov, M., Sigsgaard, C., Dlugokencky, E. J., Houweling, S., Ström L., Tamstorf, M. P., and Christensen, T. R.: Large tundra methane burst during onset of freezing, Nature, 456, 628-631, 2008.

McEwing, K. R., Fisher, J. P., and Zona, D.: Environmental and vegetation controls on the spatial variability of $\mathrm{CH}_{4}$ emission from wet-sedge and tussock tundra ecosystem in the Arctic, Plant Soil, 388, 37-52, 2015.

Melton, J. R., Wania, R., Hodson, E. L., Poulter, B., Ringeval, B., Spahni, R., Bohn, T., Avis, C. A., Beerling, D. J., Chen, G., Eliseev, A. V., Denisov, S. N., Hopcroft, P. O., Lettenmaier, D. P., Riley, W. J., Singarayer, J. S., Subin, Z. M., Tian, H., Zürcher, S., Brovkin, V., van Bodegom, P. M., Kleinen, T., Yu, Z. C., and Kaplan, J. O.: Present state of global wetland extent and wetland methane modelling: conclusions from a model intercomparison project (WETCHIMP), Biogeosciences, 10, 753788, doi:10.5194/bg-10-753-2013, 2013.

Meng, L., Hess, P. G. M., Mahowald, N. M., Yavitt, J. B., Riley, W. J., Subin, Z. M., Lawrence, D. M., Swenson, S. C., Jauhiainen, J., and Fuka, D. R.: Sensitivity of wetland methane emissions to model assumptions: application and model testing against site observations, Biogeosciences, 9, 2793-2819, doi:10.5194/bg-92793-2012, 2012.

Mialon, A., Royer, A., and Fily, M.: Wetland seasonal dynamics and interannual variability over northern high latitudes, derived from microwave satellite data, J. Geophys. Res., 110, D17102, doi:10.1029/2004JD005697, 2005.

Moosavi, S. C., Crill, P. M., Pullman, E. R., Funk, D. W., and Peterson, K. M.: Controls on $\mathrm{CH}_{4}$ flux from an Alaskan boreal wetland, Global Biogeochem. Cy., 10, 287-296, 1996.

Morin, T. H., Bohrer, G., Naor-Azrieli, L., Mesi, S., Kenny, W. T., Mitsch, W. J., and Schäfer, K. V. R.: The seasonal and diurnal dynamics of methane flux at a created urban wetland, Ecol. Engin., $72,74-83,2014$
Peters, W., Jacobson, A. R., Sweeney, C., Andrews, A. E., Conway, T. J., Masarie, K., Miller, J. B., Bruhwiler, L. M. P., Petron, G., Hirsch, A., Worthy, D. E. J., van der Werf G. R., Randerson, J. T., Wennberg, P. O., Krol, M. C., and Tans, P. P.: An Atmospheric perspective on north American carbon dioxide exchange: CarbonTracker, P. Natl. Acad. Sci. USA, 18925-18930, 2007.

Pickett-Heaps, C. A., Jacob, D. J., Wecht, K. J., Kort, E. A., Wofsy, S. C., Diskin, G. S., Worthy, D. E. J., Kaplan, J. O., Bey, I., and Drevet, J.: Magnitude and seasonality of wetland methane emissions from the Hudson Bay Lowlands (Canada), Atmos. Chem. Phys., 11, 3773-3779, doi:10.5194/acp-11-3773-2011, 2011.

Prigent, C., Papa, F., Aires, F., Rossow, W. B., and Matthews, E. Global inundation dynamics inferred from multiple satellite observations, 1993-2000, J. Geophys. Res.-Atmos., 112, D12107, doi:10.1029/2006JD007847, 2007.

Qian, T. T., Dai, A., Trenberth, K. E., and Oleson, K. W.: Simulation of global land surface conditions from 1948 to 2004, Part I: Forcing data and evaluations, J. Hydrometeorol., 7, 953-975, 2006.

Riley, W. J., Subin, Z. M., Lawrence, D. M., Swenson, S. C., Torn, M. S., Meng, L., Mahowald, N. M., and Hess, P.: Barriers to predicting changes in global terrestrial methane fluxes: analyses using CLM4Me, a methane biogeochemistry model integrated in CESM, Biogeosciences, 8, 1925-1953, doi:10.5194/bg-8-19252011, 2011.

Ringeval, B., de Noblet-Ducoudré, N., Ciais, P., Bousquet, P., Prigent, C., Papa, F., and Rossow, W. B.: An attempt to quantify the impact of changes in wetland extent on methane emissions on the seasonal and interannual time scales, Global Biogeochem. Cy., 24, GB2003, doi:10.1029/2008GB003354, 2010.

Rinne, J., Riutta, T., Pihlatie, M., Aurela, M., Haapanala, S., Tuovinen, J., and Tuittila, E.: Annual cycle of methane emission from a boreal fen measured by the eddy Covance technique, Tellus, 59B, 449-457, 2007.

Roulet, N. T., Ash, R., and Moore, T. R.: Low boreal wetlands as a source of atmospheric methane, J. Geophys. Res., 97, 37393749, 1992.

Schroeder, R., McDonald K. C., Champan, B. D., Jensen, K., Podest, E., Tessler, Z. D., Bohn, T. J., and Zimmermann, R.: Development and evaluation of a multi-year fractional surface water data set derived from active/passive microwave remote sensing data, 7, 16688-16732, 2015.

Segers, R.: Methane production and methane consumption: a review of process underlying wetland methane fluxes, Biogeochemistry, $41,23-51,1998$

Sloan, V.: Plant roots in Arctic ecosystems: stocks and dynamics and their coupling to aboverground parameters, $\mathrm{PhD}$ Thesis, University of Sheffield, Sheffield, UK, 2011.

Song, C., Xu, X., Sun, X., Tian, H., Sun, L., Miao, Y., Wang, X., and Guo, Y.: Large methane emission upon spring thaw from natural wetlands in the northern permafrost region, Environ. Res. Lett., 7, 034009, doi:10.1088/1748-9326/7/3/034009, 2012.

Sturtevant, C. S., Oechel, W. C., Zona, D., Kim, Y., and Emerson, C. E.: Soil moisture control over autumn season methane flux, Arctic Coastal Plain of Alaska, Biogeosciences, 9, 1423-1440, doi:10.5194/bg-9-1423-2012, 2012.

Sullivan, P. F. and Welker, J. M.: Warming chambers stimulate early season growth of an arctic sedge: results of a minirhizotron field study, Oecologia, 142, 616-626, 2005 
Tian, Y, Dickinson, R. E., Zhou, L., Zeng, X., Dai, Y., Myneni, R. B., Knyazikhin, Y., Zhang, X., Friedl, M., Yu, H., Wu, W., and Shaikh, M.: Comparison of seasonal and spatial variations of leaf area index and fraction of absorbed photosynthetically active radiation from Moderate Resolution Imaging Spectroradiometer (MODIS) and Common Land Model, J. Geophys. Res., 109, D01103, doi:10.1029/2003JD003777, 2004.

Tokida, T., Mizoguchi, M., Miyazaki, T., Kagemoto, A., Nagata, O., and Hatano, R.: Episodic release of methane bubbles from peatland during spring thaw, Chemosphere, 70, 165-171, 2007.

Torn, M. S. and Chapin III, F. S.: Environmental and biotic controls over methane flux from arctic tundra, Atmos. Environ., 32, 32013218, 1993.

van Fischer, J. C., Rhew, R. C., Ames, G. M., Fosdick, B. K., and von Fischer, P. E.: Vegetation height and other controls of spatial variability in methane emissions from the Arctic coastal tundra at Barrow, Alaska, J. Geophys. Res., 115, G00I03, doi:10.1029/2009JG001283, 2010

van Hulzen J. B., Segers, R., van Bodegom, P. M., and Leffelaar, P. A.: Temperature effects on soil methane production: and explanation for observed variability, Soil Biol. Biochem., 31, 19191929, 1999.

van Winden, J. F., Reichart, G.-J., McNamara, N. P., Benthien, A., and Damsté, J. S. S.: Temperature-induced increase in methane release from peat bogs: a mesocosm experiment, PLoS ONE 7, e39614, doi:10.1371/journal.pone.0039614, 2012.

Wania, R., Ross, I., and Prentice, I. C.: Implementation and evaluation of a new methane model within a dynamic global vegetation model: LPJ-WHyMe v1.3.1, Geosci. Model Dev., 3, 565-584, doi:10.5194/gmd-3-565-2010, 2010.
Whalen, S. C. and Reeburgh, W. S.: Consumption of atmospheric methane by tundra soils, Nature, 342, 160-162, 1990.

Wickland, K. P., Striegl, R. G., Schmidt, S. K., and Mast, M. A.: Methane flux in subalpine wetland and unsaturated soils in the southern Rocky Mountains, Global Biogeochem. Cy., 13, 101113, 1999.

Wilson, J. O., Crill, P. M., Bartlett, K. B., Sebacher, D. I., Harriss, R. C., and Sass, R. L.: Seasonal variation of methane emissions from a temperate swamp, Biogeochemistry, 8, 55-71, 1998.

Yvon-Durocher, G., Allen, A. P., Bastviken, D., Conrad, R., Gudasz, C., St-Pierre, A., Thanh-Duc, N., and del Giorgio, P. A.: Methane fluxes show consistent temperature dependence across microbial to ecosystem scale, Nature, 507, 488-491, 2014.

Zhuang, Q., Melillo, J. M., Kicklighter, D. W., Prinn, R. G., McGuire, A. D., Steudler, P. A., Felzer, B. S., and Hu, S.: Methane fluxes between terrestrial ecosystems and the atmosphere at northern high latitudes during the past century: A retrospective analysis with a process based biogeochemistry model, Global Biogeochem. Cy., 18, GB3010, doi:3010.1029/2004GB002239, 2004.

Zona, D., Gioli, B., Commane, R., Lindaas, J., Wofsy, S. C., Miller, C. E., Dinardo, S. J., Dengel, S., Sweeney, C., Karion, A., Chang, R.Y.-W., Henderson, J. M., Murphy, P. C., Goodrich, J. P., Moreaux, V., Liljedahl, A., Watts, J. D., Kimball, J. S., Lipson, D. A., and Oechel, W. C.: Cold season emissions dominate the Arctic tundra methane budget, P. Natl. Acad. Sci. USA, 113, 40-45, 2016. 